\title{
Sea ice and primary production proxies in surface sediments from a High Arctic Greenland fjord: Spatial distribution and implications for palaeoenvironmental studies
}

\author{
Sofia Ribeiro, Mikael K. Sejr, Audrey Limoges, Maija Heikkilä, Thorbjørn Joest Andersen, \\ Petra Tallberg, Kaarina Weckström, Katrine Husum, Matthias Forwick, Tage Dalsgaard, \\ Guillaume Massé, Marit-Solveig Seidenkrantz, Søren Rysgaard
}

\begin{abstract}
In order to establish a baseline for proxy-based reconstructions for the Young Sound-Tyrolerfjord system (Northeast Greenland), we analysed the spatial distribution of primary production and sea ice proxies in surface sediments from the fjord, against monitoring data from the Greenland Ecosystem Monitoring Programme. Clear spatial gradients in organic carbon and biogenic silica contents reflected marine influence, nutrient availability and river-induced turbidity, in good agreement with in situ measurements. The sea ice proxy $\mathrm{IP}_{25}$ was detected at all sites but at low concentrations, indicating that $\mathrm{IP}_{25}$ records from fjords need to be carefully considered and not directly compared to marine settings. The sea ice-associated biomarker HBI III revealed an open-water signature, with highest concentrations near the mid-July ice edge. This proxy evaluation is an important step towards reliable palaeoenvironmental reconstructions that will, ultimately, contribute to better predictions for this High Arctic ecosystem in a warming climate.
\end{abstract}

Keywords Arctic sea ice - Greenland fjords · HBIs · Primary production $\cdot$ Proxies $\cdot$ Silica

\section{INTRODUCTION}

The thinning and retreat of Arctic sea ice is one of the most striking consequences of recent climate change, and has a very significant impact on Arctic ecosystem functioning (Wassmann et al. 2011). In the Arctic Ocean, sea ice retreat has led to an increase in light availability and a ca. $30 \%$ net primary production growth during the past two decades. However, this pattern is not uniform over the Arctic and a decline of about $15 \%$ in primary production has been reported for the Greenland Sea region (Arrigo and van Dijken 2015).

Studies along the latitudinal gradient in sea ice cover around Greenland show a significant impact of sea ice on productivity of both primary (Krause-Jensen et al. 2012) and secondary producers (Sejr et al. 2009). This suggests that any future changes in sea ice cover will impact the marine ecosystem. The polynyas and fjords of Northeast Greenland contribute significantly to the primary productivity of this region. Consequently, the need to understand ecosystem structure and function and to quantify possible changes for these marine systems influenced by a seasonal ice cover has led to monitoring efforts such as the Greenland Ecosystem Monitoring (GEM) Program. A large number of projects have focused on the Young Sound (e.g. Rysgaard and Glud 2007 and references therein). Today, this is one of the most studied High Arctic fjord systems in the world and can be considered a "natural laboratory".

The Young Sound-Tyrolerfjord system is characterized by seasonal sea ice cover, with the ice-free season extending from approximately late July to late October (Sejr et al. 2011). The presence of sea ice determines the timing of pelagic primary production, which starts during the latest stage of sea ice melt and peaks when the ice disappears (Rysgaard et al. 1999). The surface water is eventually depleted in nutrients and the biomass of phytoplankton is restricted to the lower part of the photic zone where nutrients are still available. The extended sea ice cover combined with poor nutrient conditions limits productivity compared to other Greenland fjords such as the Godthåbsfjord system and the Disko Bay (Sejr et al. 2014; Meire et al. 2016). In addition to the phytoplankton production in the water column, sea ice microalgae that inhabit the sea ice matrix may contribute significantly to primary 
production, especially during spring and early summer. However, the biomass of ice algae and their productivity in Young Sound appears to be relatively low (Rysgaard et al. 2001). Benthic microalgae are also found in abundance on the seafloor where they contribute significantly to the total production of the outer part of Young Sound, especially at shallow depths (Attard et al. 2016).

Current research and monitoring activities in this High Arctic fjord system provide an invaluable insight into changes occurring at weekly, seasonal, and interannual time-scales, but in order to place recent changes in a longer-term context and to better constrain future scenarios for this region, it is necessary to reconstruct key parameters such as sea ice and primary production variability over multi-decadal to millennial time-scales. However, historical observation data for Northeast Greenland are particularly incomplete, and high-resolution marine sediment core records from this region are scarce. In order to address this, marine sediment-coring campaigns targeting the Young Sound, other Northeast Greenland fjords and the East Greenland shelf took place between 2013 and 2015, partly in connection with the Arctic Science Partnership (Greenlandic-Danish-Canadian Research collaboration ${ }^{1}$ ) and the TUNU Programme in Norway (Christiansen 2012).

Past environmental and climate variability prior to human observations can only be reconstructed from geological records by the use of indirect (proxy) data. Examples of primary production tracers are the organic carbon content of sediments (TOC), which can be used as a basic proxy for organic matter production and mineralization, as well as biogenic silica, an indicator of siliceous-mainly diatom-production. A relatively large number of proxies may be used to trace the presence and variability of sea ice (primarily dinoflagellate cysts, diatoms, and biomarkers, see de Vernal et al. 2013 and references therein). One such proxy is based on the abundance of a biomolecule termed $\mathrm{IP}_{25}$-ice proxy with 25 carbon atoms - a highly branched isoprenoid (HBI) lipid, which is synthesized in the sea ice matrix by some species of sea ice diatoms (Brown et al. 2014). Since the discovery of this Arctic sea ice proxy (Belt et al. 2007), an increasing number of palaeo-sea ice reconstructions based on $\mathrm{IP}_{25}$ have been produced (e.g. Massé et al. 2008; Müller et al. 2012; Belt et al. 2015), although reports of $\mathrm{IP}_{25}$ in Arctic fjords are rare (CabedoSanz et al. 2013; Brown et al. 2015). It has been suggested that more detailed interpretations of the past sea ice conditions can be obtained through the comparison between $\mathrm{IP}_{25}$ and a related lipid biomarker (HBI III), which is likely produced by diatoms blooming in the open-water environment of the marginal ice zone (Belt et al. 2015; Smik et al. 2016). As such, the relative contributions to the

\footnotetext{
1 www.asp-net.org
}

sediment of endemic sea ice versus ice-edge phytoplankton can provide insights into past sea ice dynamics, and seasonal sea ice evolution.

The amount and quality of information available for the Young Sound fjord system provides an exceptional opportunity to evaluate the spatial distribution of these proxies against present-day conditions-a necessary first step for reliable palaeo-reconstructions. The main goal of this study is, thus, to provide a first evaluation of sedimentary signatures of primary production and seasonal sea ice along the fjord system (sediment core-top samples) in comparison with the present-day seasonal and interannual variability of these parameters (GEM data). This study defines a baseline for future palaeo-reconstruction studies using sediment core records from this region.

\section{MATERIALS AND METHODS}

\section{Present-day conditions in the fjord}

As part of the MarineBasis program, a hydrographic transect covering approximately $120 \mathrm{~km}$ is sampled every year in early August to quantify physical and biochemical properties in the Young Sound-Tyrolerfjord system (since 2003). Vertical profiles of salinity, temperature, oxygen, turbidity, and fluorescence are measured at approximately 30 stations using a Seabird 19+ CTD (Conductivity-TemperatureDepth) instrument with the appropriate sensors. In 2014, the monitoring program was complemented by additional measurements conducted in July, September, and October.

\section{Surface sediment samples}

A total of 13 sediment core-top samples were selected from four sediment-coring campaigns in the Young Sound in the years 2013-2015 (Table 1). Sample sites were chosen in order to cover the area from the Young Sound entrance to the inner part of Tyrolerfjorden, ranging from 60 to $344 \mathrm{~m}$ water depth (Fig. 1; Table 1). Three different coring devices were used (kayak corer, Rumohr lot and multi-corer) to recover undisturbed surface sediments. Samples represent the upper $0.5-1 \mathrm{~cm}$ of the cores and were freeze-dried and kept at $-80{ }^{\circ} \mathrm{C}$ until further processing.

\section{Grain-size distribution and age control}

Primary particle size measurements were carried out by ultrasonically dispersing ( 2 min on a Bandelin UW 2200) the sediment in a sodium pyrophosphate-solution and analysing the dispersed particles on a Malvern Mastersizer $\mathrm{E} / 2000$. The dispersion was wet-sieved at $1 \mathrm{~mm}$ prior to analysis in the Malvern Mastersizer and no large particles 
Table 1 Surface sediment samples selected for biogenic proxy analyses, listed from the outer Young Sound (YST1) to the innermost site in Tyrolerfjord (YST13)

\begin{tabular}{|c|c|c|c|c|c|c|}
\hline Sediment sample & Core/site designation & Water depth (m) & Latitude & Longitude & Campaign & Coring device \\
\hline YST1 & SD60 & 60 & 74.3106 & -20.2433 & ARC/IGN15 & Kayak corer \\
\hline YST2 & YS163 & 163 & 74.3097 & -20.3 & ARC/ASP13 & Rumohrlot \\
\hline YST3 & HH13-25F & 167 & 74.3667 & -20.3412 & UiT13 & Multi-corer \\
\hline YST4 & YS3.14 & 150 & 74.4212 & -20.5074 & ARC/ASP14 & Rumohrlot \\
\hline YST5 & HH13-23E & 183 & 74.4341 & -20.6483 & UiT13 & Multi-corer \\
\hline YST6 & $\mathrm{Z} 60$ & 60 & 74.4586 & -20.6493 & ARC/IGN15 & Kayak corer \\
\hline YST7 & YS3.18 & 230 & 74.4343 & -20.7573 & ARC/IGN15 & Kayak corer \\
\hline YST8 & HH13-21 & 240 & 74.4394 & -20.8713 & UiT13 & Multi-corer \\
\hline YST9 & YSD & 280 & 74.4644 & -21.1864 & ARC/IGN15 & Kayak corer \\
\hline YST10 & HH13-19 & 344 & 74.4589 & -21.3164 & UiT13 & Multi-corer \\
\hline YST11 & Tyro-8 & 160 & 74.4397 & -21.6997 & ARC/ASP14 & Rumohrlot \\
\hline YST12 & Tyro-5 & 125 & 74.5025 & -21.888 & ARC/ASP13 & Rumohrlot \\
\hline YST13 & Tyro100 & 100 & 74.6025 & -22.086 & ARC/IGN15 & Kayak corer \\
\hline
\end{tabular}

ARC Arctic Research Center, IGN Department of Geosciences and Natural Resource Management at Copenhagen University, ASP Arctic Science Partnership, UiT The Arctic University of Norway, Department of Geosciences

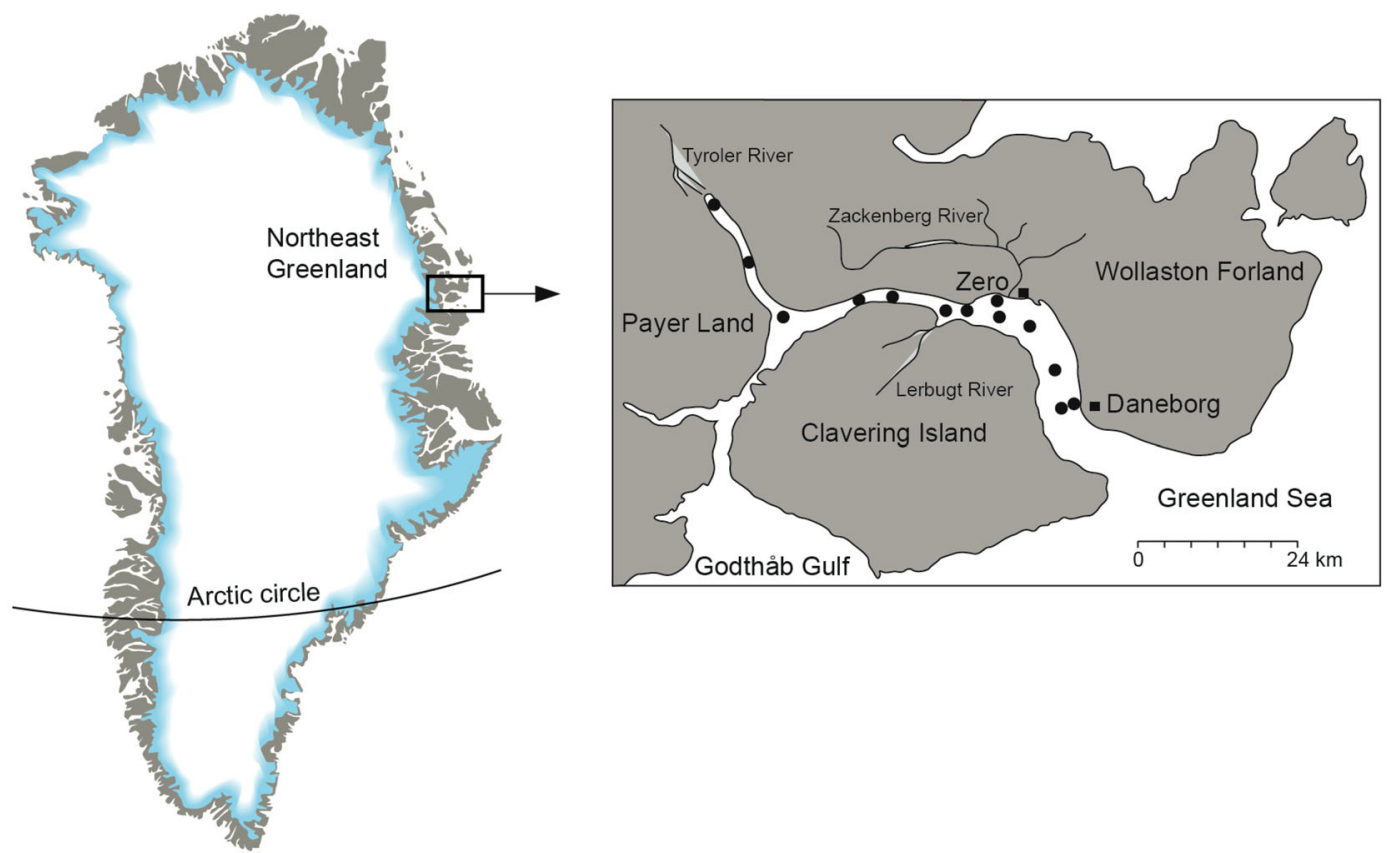

Fig. 1 Location of Young Sound-Tyrolerfjord in Northeast Greenland. Surface sediment sample sites are marked as dots

were retained on the sieve. The grain-size distribution of the samples is given here as \% clay, silt and sand.

In order to confirm that the sediments integrate a present-day signal of processes occurring in the fjord, all samples were analysed for the activity of ${ }^{210} \mathrm{~Pb},{ }^{226} \mathrm{Ra}$ and ${ }^{137} \mathrm{Cs}$ via gamma spectrometry at the Gamma Dating Center, Department of Geosciences and Natural Resource Management, University of Copenhagen. The measurements were carried out on Canberra ultralow-background
Ge-detectors. ${ }^{210} \mathrm{~Pb}$ was measured via its gamma-peak at $46.5 \mathrm{keV},{ }^{226} \mathrm{Ra}$ via the granddaughter ${ }^{214} \mathrm{~Pb}$ (peaks at 295 and $352 \mathrm{keV}$ ) and ${ }^{137} \mathrm{Cs}$ via its peak at $661 \mathrm{keV}$.

\section{Carbon analyses}

Two sample sets, one for total carbon (TC) analysis and one for total organic carbon (TOC) analysis, were established to determine the carbon contents of the sediments. 
Freeze-dried sample materials were placed in 10-ml test tubes and the samples were then rinsed twice with distilled water to remove the salt residue. The samples in the TOC set were further treated with $10 \%$ hydrogen chloride $(\mathrm{HCl})$ for $24 \mathrm{~h}$ to remove inorganic carbon. After $24 \mathrm{~h}$, the samples were checked for acidity with litmus paper and as all of them maintained acidic solution, no further acid treatments were carried out. The samples were rinsed with deionized water until the $\mathrm{pH}$ of the supernatant reached that of the deionized water. Both the TC and the TOC set of samples were then freeze-dried again. A known quantity (9-150 mg) of freeze-dried material was weighed and packed into a tin $(\mathrm{Sn})$ capsule. Carbon contents were analysed using a MICRO CUBE Elemental Vario elemental analyzer (EA) at the Laboratory of Geochemistry in the University of Helsinki with lake sediment (LKSD-4) as a reference material. Uncertainty, based on duplicate and triplicate measurements of the actual samples, is within $\pm 0.1 \%$.

\section{Biogenic silica analyses}

The amorphous or biogenic $\mathrm{Si}$ (BSi) concentration in the sediment was analysed from freeze-dried sediment samples using the $1 \% \quad \mathrm{Na}_{2} \mathrm{CO}_{3}$ extraction method with mineral correction (DeMaster 1991). Samples of $30 \pm 2 \mathrm{mg}$ of sediment (2-3 replicates) were extracted in a $1 \% \quad \mathrm{Na}_{2} \mathrm{CO}_{3}$ solution in a water bath at $85{ }^{\circ} \mathrm{C}$ for $5 \mathrm{~h}$. Subsamples of $1 \mathrm{ml}$ were withdrawn after 180, 240 and $300 \mathrm{~min}$ and neutralized with $9 \mathrm{ml}$ of $0.021 \mathrm{~N} \mathrm{HCl}$. The Si concentration in the subsamples was analysed using a spectrophotometer (Perkin Elmer lambda 25UV/VIS spectrometer) according to the blue ammonium molybdate method (Mullin and Riley 1955). The BSi concentration in each sediment sample was inferred from the intercept of the linear regression equation obtained by plotting the increase in $\mathrm{Si}$ against time, assuming that all amorphous, biogenic Si had dissolved after $2 \mathrm{~h}$ of extraction, while mineral Si dissolved continuously at a constant rate during the 5-h extraction (see e.g. Barão et al. 2015 for further details).

\section{HBI analyses (IP 25 and HBI III)}

Highly branched isoprenoid (HBI) analyses were conducted according to the procedure described in Belt et al. (2007). Prior to analytical treatment, an internal standard (7-hexylnonadecane) was added to ca. $0.5 \mathrm{~g}$ of freeze-dried and homogenized sediment. Total lipids were ultrasonically extracted $(\times 3)$ using a mixture of dichloromethane (DCM: $\left.\mathrm{CH}_{2} \mathrm{Cl}_{2}\right)$ and methanol $(\mathrm{MeOH})(2: 1, \mathrm{v} / \mathrm{v})$. Extracts were pooled together and the solvent was removed by evaporation under a slow stream of nitrogen. The total extract was subsequently re-suspended in hexane and purified through an open column chromatography $\left(\mathrm{SiO}_{2}\right)$. Hydrocarbons (including $\mathrm{IP}_{25}$ and $\mathrm{HBI}$ III) were eluted using hexane. Procedural blanks and standard sediments were analysed in between every 15 samples. Hydrocarbon fractions were analysed using an Agilent 7890 gas chromatograph (GC) fitted with a 30-m fused silica Agilent HP5-MS column $(0.25 \mathrm{~mm}$ i.d. and $0.25 \mu \mathrm{m}$ phase thickness) and coupled to an Agilent 5975C Series mass selective detector (MSD). Oven temperatures were programmed as follows: $40-300{ }^{\circ} \mathrm{C}$ at $10^{\circ} \mathrm{C} \mathrm{min}^{-1}$, followed by an isothermal interval at $300{ }^{\circ} \mathrm{C}$ for $10 \mathrm{~min}$. The data were collected using Chemstation and analysed using the MassHunter quantification software. $\mathrm{IP}_{25}$ and HBI III were identified on the basis of retention time and comparison of mass spectra with authenticated standards. Abundances were obtained by comparison between individual GC-MS responses relative to those of the internal standard. Data are reported here in $\mathrm{ng} \mathrm{g}^{-1}$.

\section{RESULTS AND DISCUSSION}

\section{Present-day conditions in the fjord}

Satellite images from 2014 show the typical seasonal sea ice development in Young Sound (Fig. 2). The area is covered by landfast sea ice that reaches a maximum around February and March. During May and June, the ice-free area outside Young Sound gradually expands. In June, meltwater ponds start to form on top of the sea ice, and in early July, open water is often visible in the inner part of the Tyrolerfjord. In late July, the remaining sea ice is flushed out of the fjord, which remains largely ice-free until October or November, when ice forms again depending on wind conditions (Fig. 2).

The surface salinity is influenced by the melting sea ice, which combined with meltwater from land creates a shallow 5-10 m lens of warm, low-salinity surface water (Fig. 3a, b). Lowest salinity is observed in the inner Tyrolerfjord where it may be below 15 psu and gradually increases towards the fjord entrance. As freshwater input from land typically terminates by early September, the surface layer becomes gradually mixed into deeper water and the freshwater is distributed more evenly in the upper $30-50 \mathrm{~m}$ of the water column (Figs. 3b, 4). In August, the three larger rivers (Tyroler River, Lerbugt River, and Zackenberg River; Fig. 1) all export large amounts of particles causing high turbidity, particularly in the inner part of the fjord (zone C) that is directly impacted by glacial rivers (Fig. 3e). The high turbidity absorbs most of the sunlight in the shallow surface lens, which is consequently heated to more than $10{ }^{\circ} \mathrm{C}$. Under this warm surface layer, temperatures are below $0{ }^{\circ} \mathrm{C}$, except on the shelf 

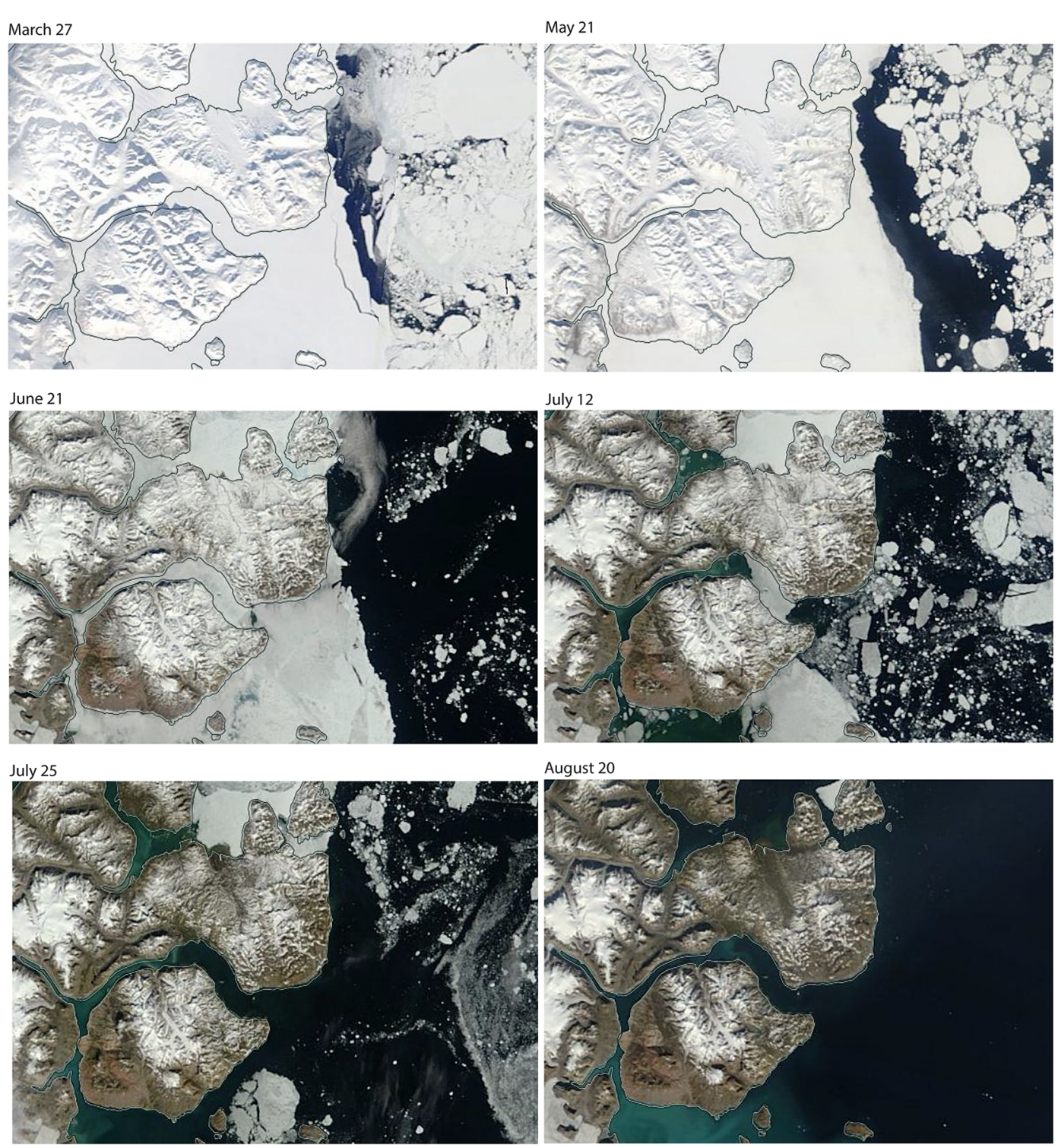

August 20
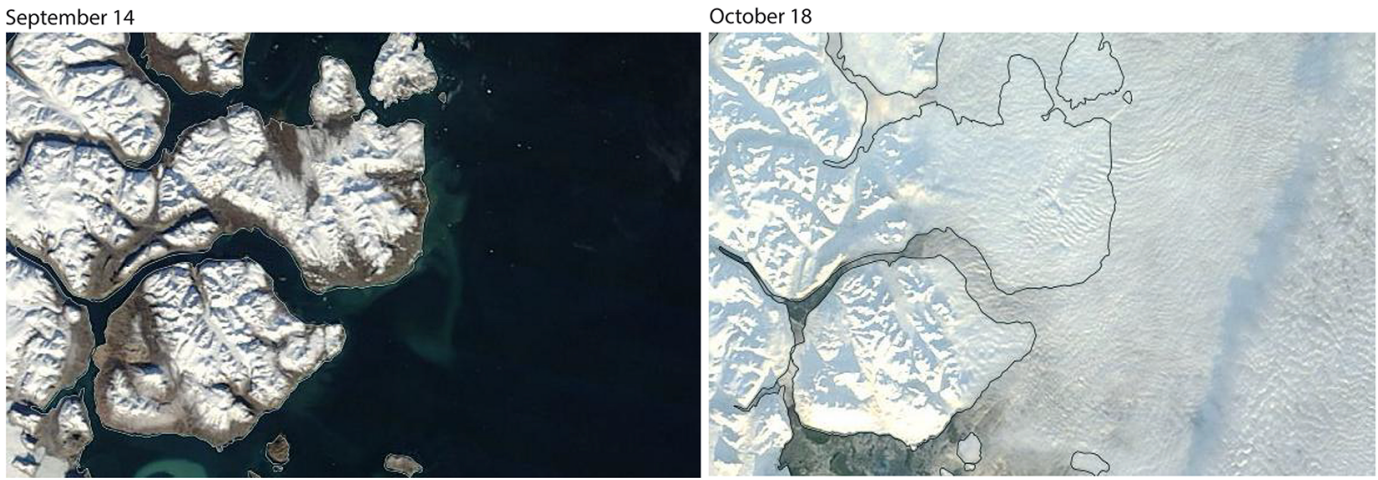

Fig. 2 Seasonal sea ice conditions in the fjord (based on MODIS imagery) for the year 2014

outside the fjord, where warm Atlantic subsurface water (Irminger Water) is found below $200 \mathrm{~m}$ depth (Fig. 3a). The high turbidity and consequently poor light conditions are reflected in very low levels of fluorescence-a proxy for phytoplankton biomass-in the inner fjord part. In August, the peak in fluorescence is typically found in the outer fjord due to a combination of more favourable light and nutrient conditions (Fig. 3d, zone A). Fluorescence 

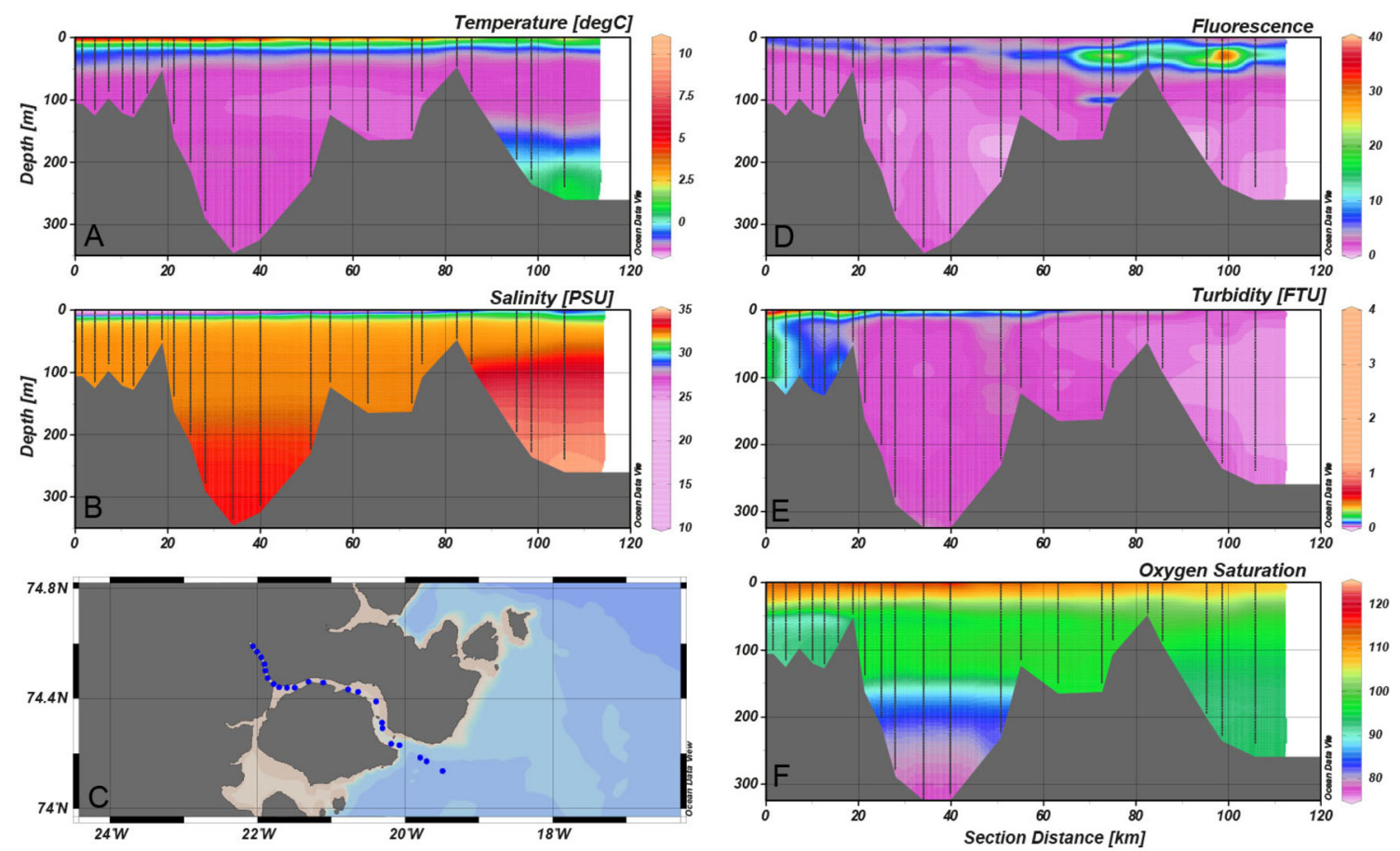

Fig. 3 Contour plots of key hydrographical parameters along the fjord in early August (2014). CTD casts are marked as black vertical lines on the transects. a Temperature, b salinity, $\mathbf{c}$ blue dots show the location of the CTD stations, $\mathbf{d}$ fluorescence, e turbidity, $\mathbf{f}$ oxygen saturation

levels decrease in the outer part of the fjord during the icefree period (July-October) and increase slightly in the upper $40 \mathrm{~m}$ of the fjord waters (Fig. 4). Oxygen levels in the fjord are mostly close to saturation, with a slight oversaturation in areas of phytoplankton production (surface waters) and under-saturation equivalent to $70-80 \%$ in the bottom waters of the deepest basin (Fig. 3f, zone B).

\section{Surface sediment samples}

\section{Grain size and age control}

All surface sediment samples consisted of silt and sandy silt (Fig. 5), and the grain-size distribution was relatively uniform, not following a clear pattern with depth or distance in the fjord. Only the innermost fjord sample (YS13) contained more than $20 \%$ sand (Fig. 5).

The presence of unsupported ${ }^{210} \mathrm{~Pb}$ confirms that the sediment is recent, and has been deposited $<100$ years ago, most likely very recently. One sample (YST13) did not show measurable content of unsupported ${ }^{210} \mathrm{~Pb}$ but this may be caused by the sandy nature of the sample (Fig. 5). Additionally, ${ }^{137} \mathrm{Cs}$ has been released into the environment since the 1950s and during the Chernobyl disaster of 1986, and the presence of this isotope in several of the samples confirms the recent nature of the material. However, the content of this isotope is generally low and close to the detection limit of about $2-3 \mathrm{~Bq} \mathrm{~kg}^{-1}$ and the absence in some of the samples therefore does not necessarily indicate deposition prior to the 1950s. On the contrary, preliminary dating of the sediment cores collected at sites YS4, YS7, YS9, and YS11, all show ${ }^{137} \mathrm{Cs}$ activity further down-core, confirming that the upper $0-1 \mathrm{~cm}$ of sediment has been deposited within the last years to decade(s).

\section{Organic carbon}

Total organic carbon (TOC) results helped to define three zones within the fjord (Fig. 6). Zone A, consisting of the samples from the outermost part of the fjord (YST1 to YST6), had values between 0.7 and $1.5 \%$. The samples from zone $\mathrm{B}$, in the middle part of the fjord, had generally lower values than zone A $(0.2-0.7 \%)$. Zone $\mathrm{C}$ consisted of the two innermost sites (YS12 and YS13) and had the lowest values of TOC $<0.1 \%$ (Fig. 6). The observed pattern in TOC is likely a result of several processes: seasonal sediment trap data from zone A show that more than $90 \%$ of the annual vertical flux of particulate organic matter occurs during the ice-free period, with nearly equal contributions from marine primary production and riverine input (Rysgaard and Sejr 2007). Since zone B and zone C are more influenced by the rivers, the contribution of terrestrial carbon is likely more important, but due to high sedimentation of inorganic particles, the organic carbon signal is "diluted" in the inner part of the fjord. Zone A of the fjord is the most productive, due to more favourable 

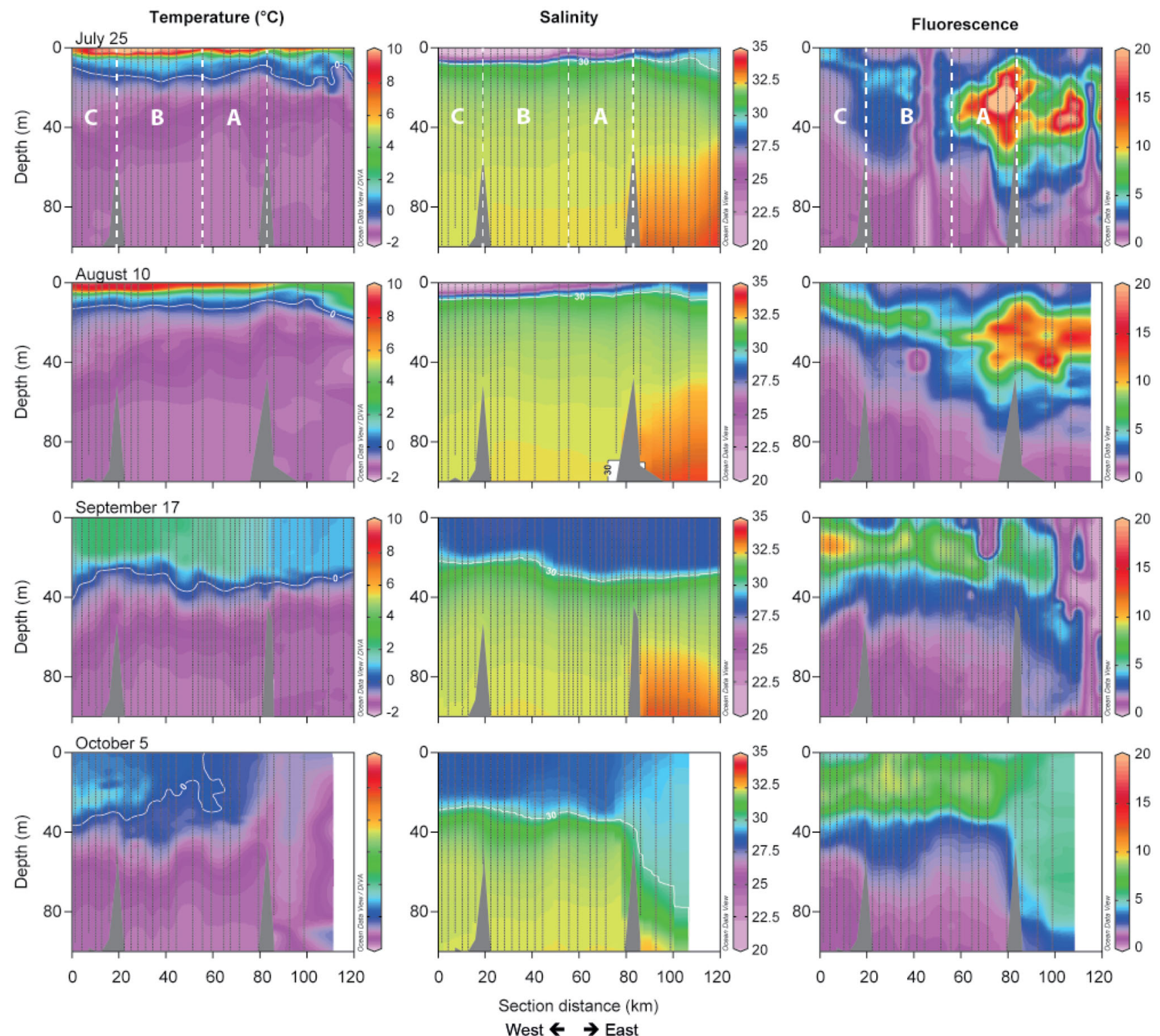

Fig. 4 Evolution of key parameters (temperature, salinity and fluorescence) along the fjord transect (Fig. 3c) during the ice-free period (lateJuly-October 2014) down to $100 \mathrm{~m}$ water depth. CTD casts are marked as black vertical lines. The distribution of zones A-C is highlighted on the top panels

light and nutrient conditions (Murray et al. 2015). The main primary producers in the outer region of the fjord are phytoplankton $(65 \%)$ and benthic algae $(34 \%)$, while the contribution of sea ice algae is minimal $(<1 \%$ according to Glud and Rysgaard 2007). Previous studies on carbon cycling in sediments from the outer Young Sound showed that about $70 \%$ of the organic carbon reaching the seafloor is oxidized (Thamdrup et al. 2007). However, at water depths higher than $80 \mathrm{~m}$, carbon burial exceeds oxidation (Rysgaard and Sejr 2007).

The generally higher TOC values for YST1 to YST6 (zone A, Fig. 6) most likely reflect organic matter fluxes originating from the phytoplankton bloom that extends from outside the fjord and past the entrance sill (as seen by the fluorescence measurements, Figs. 3, 4), likely influenced by the vertical mixing across the shallow sill (Arendt et al. 2016). Interestingly, the two lowest values measured in this zone are for YST1 and YST6, which both lie at a depth of about $60 \mathrm{~m}$, where carbon oxidation is expected to exceed burial (Thamdrup et al. 2007). The TOC values $<0.1 \%$ for YST12 and YST13 are in good agreement with the high turbidity and low fluorescence measured in this area during the summer (Figs. 3, 6), which inhibits production. 


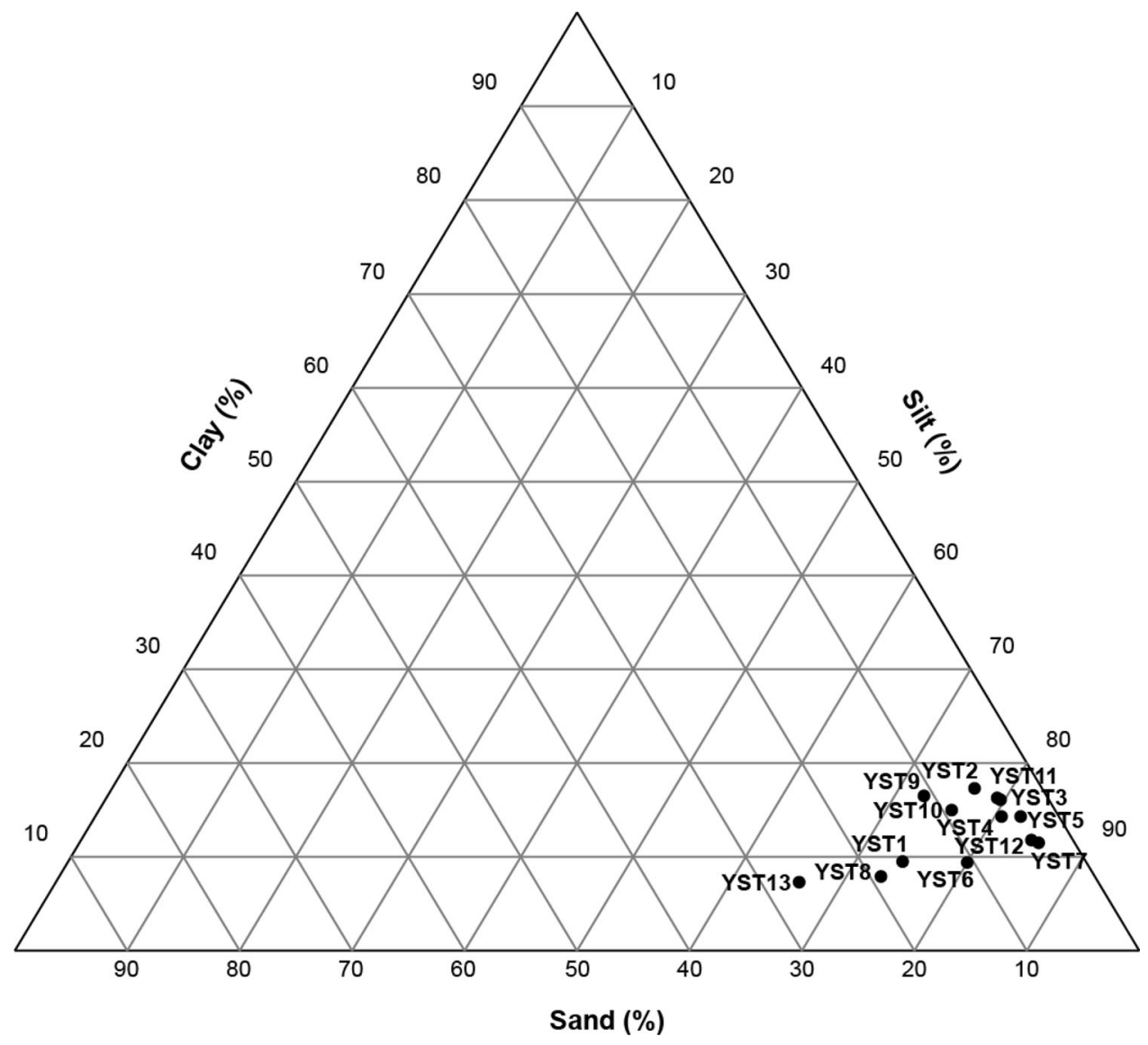

Fig. 5 Grain-size distribution of the surface sediment samples

\section{Biogenic silica}

The BSi concentration in the Young Sound-Tyrolerfjorden sediments varied between 1.3 and $9 \mathrm{mg} \mathrm{g}^{-1} \mathrm{DM} \mathrm{Si}$ (median $5.8 \mathrm{mg} \mathrm{g}^{-1}$ ), corresponding to 0.3 and $1.9 \mathrm{wt} \% \mathrm{SiO}_{2}$ (median $1.2 \mathrm{wt} \% \mathrm{SiO}_{2}$ ). Biogenic silica $(\mathrm{BSi})$ refers to the amorphous $\mathrm{Si}$ content in sediments. It is mainly used as a proxy for siliceous microfossil abundance, and it has been shown to be a useful proxy for diatom abundance and productivity in aquatic systems (Conley and Schelske 2001). Measurements of BSi from marine sediments in the Arctic region are quite scarce, but BSi concentrations in the surface Young Sound sediments are comparable to those $(<2 \%)$ measured from the Greenland Sea (Schlüter and Sauter 2000), and appear to be low compared to the study by Heikkilä et al. (2014) in surface sediment from the Hudson Bay system (2-11\%).

The BSi content in the surface sediment followed a pattern similar but not identical to the TOC values. While the latter reflects the overall trends in primary productivity in the fjord (zone A being the most productive, and zone $\mathrm{C}$ the least productive), biogenic silica reflects the interplay between the available dissolved silica from glacial meltwater and light availability. Three major glacial rivers discharge into the fjord and the total combined runoff from land has been estimated to $0.9-1.4 \mathrm{~km}^{3}$ year (Rysgaard et al. 2004; Bendsten et al. 2014), with a great impact on salinity and influx of both sediments and macronutrients. Among the macronutrients, dissolved silica is exported in large quantities from the weathering of silicate rock by glaciers. Silica is an important nutrient for diatom growth, and hence a controlling factor in primary productivity in the Young Sound-Tyrolerfjord system. Although runoff is highest in the inner parts of the fjord, biological uptake of dissolved silica does not match its availability (Rysgaard et al. 1999) in zone C, possibly due to the high turbidity here (Fig. 3). Our analyses of biogenic silica content in the surface sediment samples show that the highest concentrations were instead measured in sediments from site YST6, near the Zackenberg river mouth, where dissolved silica concentrations are high but turbidity is relatively low (see Fig. 1 in Meire et al. 2016).

During the summer, phytoplankton assemblages are largely dominated by diatoms in the outer part of the fjord, 


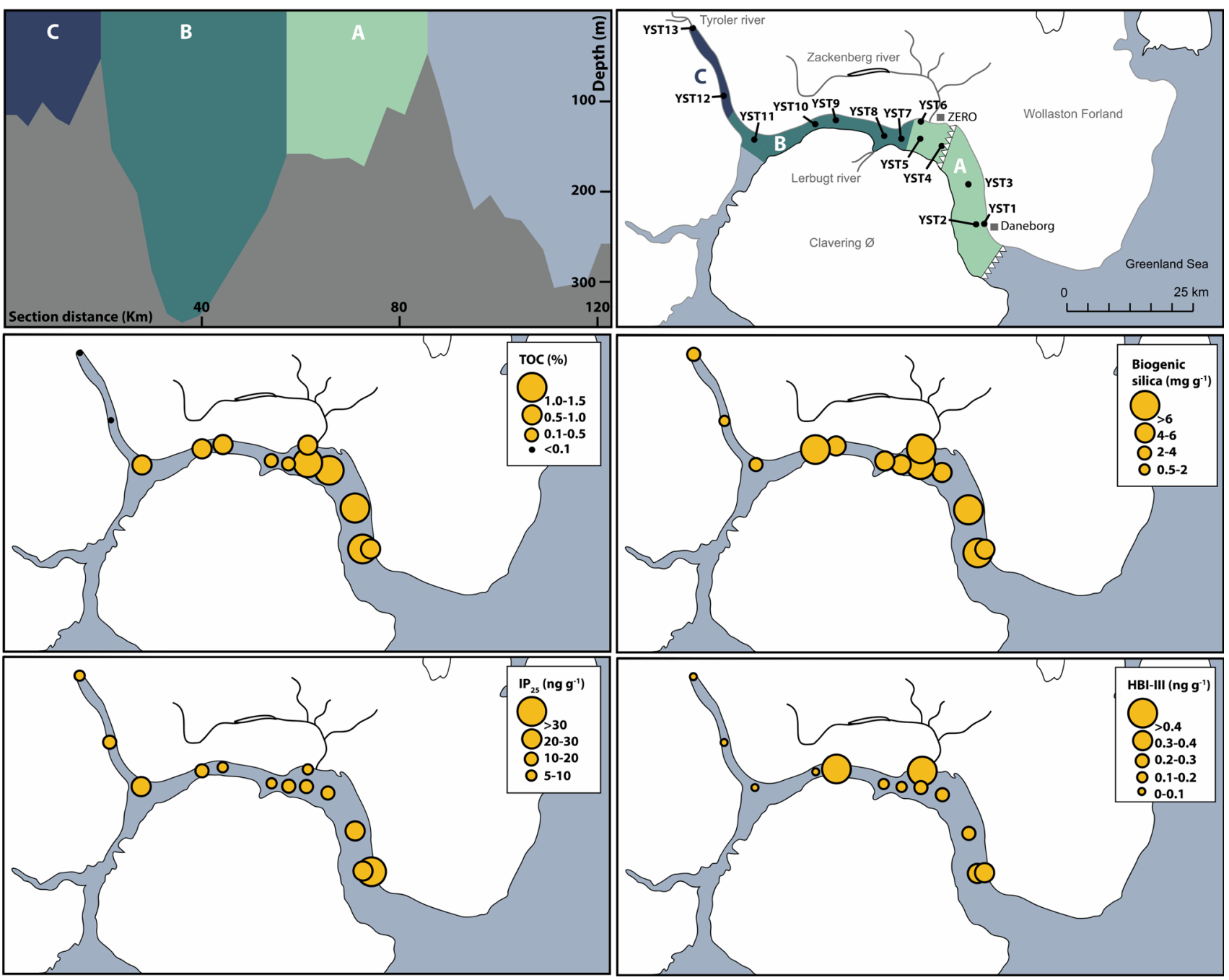

Fig. 6 Spatial distribution and abundance of biogenic proxies in the fjord sediments. The distribution of zones A-C is given in the top panels. The white series of triangles show the approximate position of the July sea ice edge

while dinoflagellates and ciliates increase in abundance towards station YST7 and colonial chrysophytes become the most abundant group around station YST12 (data from summer 2012, see Krawczyk et al. 2015 for details). These groups of organisms have very different contributions to the sediment. All diatoms and some chrysophytes will enrich the BSi silica content in the sediments, whereas the majority of dinoflagellates, ciliates and their cysts are composed of refractory organic material. These differences in phytoplankton composition appear to be reflected in the $\mathrm{BSi}$ content of the sediments, as the highest BSi concentrations were generally found in zone A, with the exception of station YS10 (Fig. 6). Although biogenic silica contents in the sediments are a tracer of both planktic and benthic diatom productivity, all the sites studied here are expected to have a very low contribution from benthic microalgae, because these are mainly found at depths $<30 \mathrm{~m}$ (Glud et al. 2002).

\section{Spatial distribution of sea ice proxies}

$\mathrm{IP}_{25}$ concentrations ranged from 8 to $42 \mathrm{ng} \mathrm{g}^{-1}$ dry sediment (Fig. 6; Table 2). The presence of $\mathrm{IP}_{25}$ at all sites primarily reflects the seasonal nature of the ice cover in the fjord. This molecule is produced by diatoms thriving in the sea ice bottom (at $1-3 \mathrm{~cm}$ from the ice-water interface, according to Brown et al. 2011), and released from the sea ice matrix during ice melt. The source of $\mathrm{IP}_{25}$ has been identified by Brown et al. (2014) as pan-Arctic diatom species belonging to the genera Haslea (H. spicula/crucerigeroides and H. kjellmanii) and Pleurosigma (P. stuxbergii var. rhomboides). Within the MarineBasis framework of the GEM Programme, phytoplankton identification counts have been performed since 2004, and the dominant diatom species at the water/sea ice interface have also been reported for the Young Sound (Glud et al. 2007). Microscopic examination of sea ice core samples from the 
Table 2 Overview of sedimentological and biogenic proxy results

\begin{tabular}{|c|c|c|c|c|c|c|c|c|c|c|c|}
\hline \multirow[t]{2}{*}{ Sample } & \multicolumn{3}{|l|}{ Grain size } & \multicolumn{4}{|c|}{ Radiometric data } & \multicolumn{4}{|l|}{ Proxy data } \\
\hline & Clay (\%) & Silt $(\%)$ & Sand $(\%)$ & $\begin{array}{l}{ }^{210} \mathrm{~Pb}_{\text {exc }} \\
\left(\mathrm{Bq} \mathrm{kg}^{-1}\right)\end{array}$ & SD & $\begin{array}{l}\left.{ }^{137} \mathrm{Cs}^{-1}\right) \\
\left(\mathrm{Bq} \mathrm{kg}^{-1}\right)\end{array}$ & SD & TOC $(\%)$ & $\begin{array}{l}\mathrm{BSi} \\
\left(\mathrm{mg} \mathrm{g}^{-1}\right)\end{array}$ & $\begin{array}{l}\mathrm{IP}_{25} \\
\left(\mathrm{ng} \mathrm{g}^{-1}\right)\end{array}$ & $\begin{array}{l}\text { HBI III } \\
\left(\mathrm{ng} \mathrm{g}^{-1}\right)\end{array}$ \\
\hline YST1 & 9.5 & 74.2 & 16.3 & 32 & 6 & 4 & 3 & 0.65 & 5.12 & 41.90 & 0.34 \\
\hline YST2 & 17.3 & 76.7 & 6.0 & 104 & 13 & 31 & 3 & 1.33 & 6.15 & 20.69 & 0.35 \\
\hline YST3 & 16.1 & 79.7 & 4.3 & 170 & 26 & 17 & 4 & 1.47 & 6.44 & 21.01 & 0.25 \\
\hline YST4 & 14.3 & 80.6 & 5.1 & 197 & 38 & 0 & 0 & 1.46 & 4.20 & 13.05 & 0.26 \\
\hline YST5 & 14.3 & 82.3 & 3.4 & 63 & 13 & 24 & 5 & 1.02 & 6.67 & 13.76 & 0.24 \\
\hline YST6 & 9.4 & 80.0 & 10.6 & 34 & 8 & 2 & 1 & 0.70 & 6.79 & 7.97 & 0.56 \\
\hline YST7 & 11.5 & 85.3 & 3.2 & 187 & 37 & 0 & 0 & 0.50 & 4.00 & 13.67 & 0.15 \\
\hline YST8 & 7.9 & 73.0 & 19.0 & 43 & 30 & 3 & 8 & 0.21 & 4.99 & 9.21 & 0.11 \\
\hline YST9 & 16.5 & 72.6 & 10.9 & 195 & 28 & 0 & 0 & 0.66 & 5.80 & 9.54 & 0.65 \\
\hline YST10 & 15.0 & 75.9 & 9.2 & 372 & 75 & 45 & 9 & 0.54 & 7.06 & 14.38 & 0.00 \\
\hline YST11 & 16.3 & 79.3 & 4.5 & 148 & 30 & 0 & 0 & 0.90 & 3.10 & 21.93 & 0.04 \\
\hline YST12 & 11.8 & 84.6 & 3.7 & 41 & 21 & 10 & 4 & N/A & 1.28 & 12.67 & 0.03 \\
\hline YST13 & 7.3 & 66.1 & 26.6 & 0 & 0 & 3 & 1 & N/A & 2.53 & 9.22 & 0.00 \\
\hline
\end{tabular}

outer fjord region revealed the presence of $\mathrm{IP}_{25}$ producers as minor contributors to sympagic (in-ice) production, supporting an in situ source of this biomarker (our unpublished results).

With the exception of site YST11, where values are comparably elevated, $\mathrm{IP}_{25}$ concentrations in the sediments are generally low along the fjord; highest concentrations are found in the outer fjord region, where conditions are closer to those of a marine setting (Figs. 3, 4). This suggests that the fjord conditions are somewhat unfavourable for $\mathrm{IP}_{25}$-producing taxa. While no studies so far have been dedicated to investigate the distribution of $\mathrm{IP}_{25}$ in Arctic fjord sediments, it has been suggested that significant river runoff could hamper the growth of sea ice algae (Xiao et al. 2013). In the Young Sound-Tyrolerfjord system, it has been shown that during spring the sea ice environment becomes structurally very dynamic due to the large freshwater input from breaking rivers and snow melt (Glud et al. 2007). Atmospheric forcing can lead to episodes of freshwater percolation through the sea ice matrix and the formation of an extensive lens of low-salinity water under the ice, with a strong impact on the sea ice environment and its biota (Glud et al. 2007). In the absence of comparable data from marine sites outside the fjord, it is difficult to clearly assess the degree to which salinity may influence $\mathrm{IP}_{25}$ production in the study area, but we do not exclude this as a possible scenario.

Triene (HBI III) values ranged from 0 to $0.7 \mathrm{ng} \mathrm{g}^{-1}$ dry sediment (Fig. 6; Table 2). While zone $\mathrm{C}$ is characterized by the near absence of HBI III, abundances were higher in sediments from the middle and outer parts of the fjord (zones $\mathrm{B}$ and $\mathrm{A}$ ). In contrast to $\mathrm{IP}_{25}$, whose production is confined to (benthic) diatoms living in the sea ice, HBI III is likely derived from marine open-water planktic diatoms [only known producers at the moment belong to Pleurosigma and Rhizosolenia (Belt et al. 2000; Rowland et al. 2001)]. The similarities between the spatial distributions of biogenic silica and HBI III support an open-water diatom production signature for this proxy. Indeed, the distribution of HBI III reflects the phytoplankton bloom occurring in end-July/August in the fjord, as seen by the fluorescence values (Figs. 3, 4) and corresponds to the overall trend in increasing diatom dominance and abundance in the middle and outer fjord areas, reported from phytoplankton samples (Krawczyk et al. 2015). Interestingly, the highest HBI III value, measured in sediments from YST9, corresponds to the site where the highest diatom abundances have been found in the water column (Krawczyk et al. 2015).

It has been suggested that HBI III-producing diatoms bloom in higher abundance in open-water areas near the sea ice edge (Belt et al. 2015; Smik et al. 2016) due to enhanced mixing and nutrient availability at the surface. Although turbidity and dissolved silica availability are certainly important factors shaping the distribution of HBI III in zone B, the proximity of the ice edge in mid-July in this area is noteworthy, as this is a stable feature of the annual sea ice evolution in the fjord (Fig. 2). Similarly, the ice-edge position may also be reflected by the relatively high HBI III values at stations YST1 and YST2 (Fig. 6).

\section{SUMMARY AND CONCLUSIONS}

Primary production proxies (organic carbon and biogenic silica), and sea ice-related biomarkers $\left(\mathrm{IP}_{25}\right.$ and HBI III) 
were analysed from 13 core-top samples along a transect from the outer Young Sound to the inner Tyrolfjorden. These proxies showed an overall good reflection of presentday conditions in the fjord, and a clear integration of the multiple factors (land-ocean-ice interactions) affecting this High Arctic ecosystem.

Organic carbon contents were $<1.5 \%$ and followed a clear gradient, with the highest values closer to the fjord entrance (except for the shallower sites, where organic matter oxidation is more intense). Biogenic silica-a proxy for siliceous, mainly diatom production-was generally higher at the outer fjord stations and sites in the middle part of the ford, where there is a combination of high input from the glacial rivers (source of dissolved silica), lower turbidity than in the innermost fjord region, and some degree of exchange with more saline and nutrient-rich waters from the outer fjord/Greenland Sea. The biomarker HBI III followed a pattern roughly similar to that of biogenic silica and appears to reflect diatom production during the ice-free period, notably the annual bloom that starts outside the fjord mouth and penetrates into the middle part of the fjord. Nonetheless, higher concentrations of this biomarker were found near the mid-July ice edge. The sea ice proxy $\mathrm{IP}_{25}$ was present at all sites in the fjord, reflecting the seasonal character of the ice cover. However, $\mathrm{IP}_{25}$ concentrations were rather low $\left(<40 \mathrm{ng} \mathrm{g}^{-1}\right)$ with the highest concentration in the outer part of the fjord. This indicates that the fjord environment is somewhat unfavourable for the growth of sea ice diatoms producing $\mathrm{IP}_{25}$. This is possibly a consequence of poor light availability due to snow cover and low salinity levels resulting from the high runoff and meltwater input. We thus recommend caution when attempting to reconstruct past sea ice variability in fjord systems using $\mathrm{IP}_{25}$ records, as our results clearly indicate that these cannot simply be extrapolated to open ocean conditions. It is expected that future warming and enhanced melt in this region will lead to changes in sea ice cover, exchange with the ocean, and an increased runoff from land-with an unpredictable impact on primary productivity in the fjord, also for sea ice-related biota. This set of proxies, applied to sediment records covering past warm climate periods (such as the Medieval Warm Period and the Holocene Climate Optimum) have the potential to constrain future scenarios for the Young Sound region in a warming climate.

Acknowledgements This study received financial support from the Villum Foundation, Denmark (Grant VKR 023454 to S. Ribeiro). Fieldwork was funded by the Arctic Research Center at Aarhus University, the Arctic Science Partnership, the TUNU Programme (Troms $\varnothing$ University, Norway), and the DANCEA programme (Ministry of Environment and food of Denmark). Data from the Greenland Ecosystem Monitoring Programme were provided by the Greenland Institute of Natural Resources, Nuuk, Greenland in collaboration with
Department of Bioscience, Aarhus University, Denmark. S. Rysgaard was funded by the Canada Excellence Research Chair Program, and M.-S. Seidenkrantz by the Danish Council for Independent Research I Natural Sciences (OceanHeat Project No. 12-126709/FNU). We are grateful to Egon Randa Frandsen, Aarhus University and personnel from GNRI (Nuuk, Greenland), who collected some of the sediment cores in 2014 from the small research vessel Aage V. Jensen. The captain and crew of R/V Helmer Hanssen are acknowledged, as well as Trine Dahl and Bjørn Runer Olsen for their support during data collection.

Open Access This article is distributed under the terms of the Creative Commons Attribution 4.0 International License (http:// creativecommons.org/licenses/by/4.0/), which permits unrestricted use, distribution, and reproduction in any medium, provided you give appropriate credit to the original author(s) and the source, provide a link to the Creative Commons license, and indicate if changes were made.

\section{REFERENCES}

Arendt, K.E., M.A. Agersted, M.K. Sejr, and T. Juul-Pedersen. 2016. Glacial meltwater influences on plankton community structure and the importance of top-down control in a NE Greenland fjord. Estuarine, Coastal and Shelf Science 183: 123-135. doi:10.1016/ j.ecss.2016.08.026.

Arrigo, K.R., and G.L. van Dijken. 2015. Continued increases in Arctic Ocean primary production. Progress in Oceanography 136: 60-70. doi:10.1016/j.pocean.2015.05.002.

Attard, K., K. Hancke, M. Sejr, and R. Glud. 2016. Benthic primary production and mineralization in a High Arctic fjord: In situ assessments by aquatic eddy covariance. Marine Ecology Progress Series 554: 35-50. doi:10.3354/meps11780.

Barão, L., F. Vandevenne, W. Clymans, P. Frings, O. Ragueneau, P. Meire, D.J. Conley, and E. Struyf. 2015. Alkaline-extractable silicon from land to ocean: A challenge for biogenic silicon determination. Limnology and Oceanography Methods 13: 329-344.

Belt, S.T., G. Massé, S.J. Rowland, M. Poulin, C. Michel, and B. Leblanc. 2007. A novel chemical fossil of palaeo sea ice: $\mathrm{IP}_{25}$. Organic Geochemistry 38: 16-27.

Belt, S.T., P. Cabedo-Sanz, L. Smik, A. Navarro-Rodriguez, S.M.P. Berben, J. Knies, and K. Husum. 2015. Identification of paleo Arctic winter sea ice limits and the marginal ice zone: Optimised biomarker-based reconstructions of late Quaternary Arctic sea ice. Earth and Planetary Science Letters 431: 127-139.

Bendsten, J., J. Mortensen, and S. Rysgaard. 2014. Seasonal surface layer dynamics and sensitivity to runoff in a high Arctic fjord (Young Sound/Tyrolerfjord, $74^{\circ} \mathrm{N}$ ). Journal of Geophysical Research: Oceans 119: 6461-6478.

Brown, T.A., S. Belt, C. Mundy, B. Philippe, G. Massé, and M. Poulin. 2011. Temporal and vertical variations of lipid biomarkers during a bottom ice diatom bloom in the Canadian Beaufort Sea: Further evidence for the use of the $\mathrm{IP}_{25}$ biomarker as a proxy for spring Arctic sea ice. Polar Biology 34: 1857-1894. doi:10.1007/s00300-010-0942-5.

Brown, T.A., S.T. Belt, A. Tatarek, and C.J. Mundy. 2014. Source identification of the Arctic sea ice proxy $\mathrm{IP}_{25}$. Nature Communications 5: 4197. doi:10.1038/ncomms5197.

Brown, T.A., E.N. Hegseth, and S.T. Belt. 2015. A biomarker-based investigation of the mid-winter ecosystem in Rijpfjorden, Svalbard. Polar Biology 38: 37-50. doi:10.1007/s00300-013-1352-2.

Cabedo-Sanz, P., S.T. Belt, J.K. Knies, and K. Husum. 2013. Identification of contrasting seasonal sea ice conditions during the Younger Dryas. Quaternary Science Reviews 79: 74-86. 
Christiansen, J. 2012. The TUNU-Programme: Euro-Arctic marine fishes-diversity and adaptation. In Adaptation and evolution in marine environments, vol I. From pole to pole, ed. G. di Prisco and C. Verde. Berlin: Springer.

Collins, L.G., C.S. Allen, J. Pike, D.A. Hodgson, K. Weckström, and G. Massé. 2013. Evaluating highly branched isoprenoid (HBI) biomarkers as a novel Antarctic sea-ice proxy in deep ocean glacial age sediments. Quaternary Science Reviews 79: 87-98.

Conley, D.J., and C.L. Schelske. 2001. Biogenic Silica. In Tracking environmental change using lake sediments, vol. 3, ed. J.P. Smol, H.J.B. Birks, and W.M. Last, 281-293. Dordrecht: Kluwer.

DeMaster, D. 1991. Measuring biogenic silica in marine sediments and suspended matter. In Geophysical monograph 63. Washington, DC: American Geophysical Union: 363-367.

Glud, R.N., and S. Rysgaard. 2007. The annual organic carbon budget of Young Sound, NE Greenland. Meddelelser om Grønland. Bioscience 58: 194-203.

Glud, R.N., M. Kühl, F. Wenzhöfer, and S. Rysgaard. 2002. Benthic diatoms of a high Arctic fjord (Young sound, NE Greenland): Importance for ecosystem primary production. Marine Ecology Progress Series 238: 15-29.

Glud, R.N., S. Rysgaard, M. Kühl, and J.W. Hansen. 2007. The sea ice in Young Sound: Implications for carbon cycling. Meddelelser om Grønland. Bioscience 58: 62-85.

Heikkilä, M., V. Pospelova, K.P. Hochheim, Z.Z.A. Kuzyk, G.A. Stern, D.G. Barber, and R.W. Macdonald. 2014. Surface sediment dinoflagellate cysts from the Hudson Bay system and their relation to freshwater and nutrient cycling. Marine Micropaleontology 106: 79-109.

Iwasaki, S., K. Takahashi, Y. Kanematsu, H. Asahi, J. Onodera, and A.C. Ravelo. 2016. Paleoproductivity and paleoceanography of the last 4.3 Myrs at IODP Expedition 323 Site U1341 in the Bering Sea based on biogenic opal content. Deep-Sea Research, Part II-Topical Studies in Oceanography 125: 145-154.

Kim, S., K. Takahashi, B.-K. Khim, Y. Kanematsu, H. Asahi, and A. Ravelo. 2014. Biogenic opal production changes during the MidPleistocene transition in the Bering Sea (IODP Expedition 323 Site U1343). Quaternary Research 81: 151-157.

Krause-Jensen, D., N. Marbà, B. Olesen, M.K. Sejr, P.B. Christensen, J. Rodrigues, P.E. Renaud, T.J. Balsby, et al. 2012. Seasonal sea ice cover as principal driver of spatial and temporal variation in depth extension and annual production of kelp in Greenland. Global Change Biology 18: 2981-2994.

Krawczyk, D.W., K.E. Arendt, T. Juul-Pedersen, M.K. Sejr, M.E. Blicher, and H. Jakobsen. 2015. Spatial and temporal distribution of planktonic protists in the East Greenland fjord and offshore waters. Marine Ecology Progress Series 538: 99-116.

März, C., B. Schnetger, and H.-J. Brumsack. 2013. Nutrient leakage from the North Pacific to the Bering Sea (IODP Site U1341) following the onset of northern hemispheric glaciation? Paleoceanography 28: 68-78.

Massé, G., S.J. Rowland, M.-A. Sicre, J. Jacob, E. Jansen, and S.T. Belt. 2008. Abrupt climate changes for Iceland during the last millennium: Evidence from high resolution sea ice reconstructions. Earth and Planetary Science Letters 269: 564-568.

Massé, G., S.T. Belt, X. Crosta, S. Schmidt, I. Snape, D.N. Thomas, and S.J. Rowland. 2011. Highly branched isoprenoids as proxies for variable sea ice conditions in the Southern Ocean. Antarctic Science 23: 487-498.

Meire, L., P. Meire, E. Struyf, D.W. Krawczyk, K.E. Arendt, J.C. Yde, T.J. Pedersen, M.J. Hopwood, S. Rysgaard, and F.J.R. Meysman. 2016. High export of dissolved silica from the Greenland Ice Sheet. Geophysical Research Letters. doi:10. 1002/2016GL070191.
Müller, J., K. Werner, R. Stein, K. Fahl, M. Moros, and E. Jansen. 2012. Holocene cooling culminates in sea ice oscillations in Fram Strait. Quaternary Science Reviews 47: 1-14.

Mullin, J., and J. Riley. 1955. The colorimetric determination of silicate with special reference to sea and natural waters. Analytica Chimica Acta 12: 162-176.

Murray, C., S. Markager, C.A. Stedmon, T. Juul-Pedersen, M.K. Sejr, and A. Bruhn. 2015. The influence of glacial melt water on biooptical properties in two contrasting Greenlandic fjords. Estuarine, Coastal and Shelf Science 163: 72-83.

Rysgaard, S., E. Frandsen, M.K. Sejr, and P.B. Christensen. 2004. The MarinBasic program-monitoring program report 2002-2003. In "Zackenberg Ecological Research Operations, ZERO”, 9th Annual Report, 2003, ed. M. Rasch and K. Caning. Copenhagen: Danish Polar Center, Ministry of Science, Technology and Innovation 2004.

Rysgaard, S., and R.N. Glud. 2007. Carbon cycling in Arctic marine ecosystems: Case study-Young Sound. Meddelelser om Grønland. Bioscience 58: 176-191.

Rysgaard, S., and M.K. Sejr. 2007. Vertical flux of particulate organic matter in a High Arctic fjord: Relative importance of terrestrial and marine sources. Meddelelser om Grønland. Bioscience 58: 110-119.

Rysgaard, S., T.G. Nielsen, and B.W. Hansen. 1999. Seasonal variation in nutrients, pelagic primary production and grazing in a high-Arctic coastal marine ecosystem, Young Sound, Northeast Greenland. Marine Ecology Progress Series 179: 13-25.

Rysgaard, S., M. Kühl, R.N. Glud, and J.W. Hansen. 2001. Biomass, production and horizontal patchiness of sea ice algae in a highArctic fjord (Young Sound, NE Greenland). Marine Ecology Progress Series 223: 15-26.

Schlüter, M., and E. Sauter. 2000. Biogenic silica cycle in surface sediments of the Greenland Sea. Journal of Marine Systems 23: 333-342.

Sejr, M.K., M.E. Blicher, and S. Rysgaard. 2009. Sea ice cover affects inter-annual and geographic variation in growth of the Arctic cockle Clinocardium ciliatum (Bivalvia) in Greenland. Marine Ecology Progress Series 389: 149-158. doi:10.3354/Meps08200.

Sejr, M.K., D. Krause-Jensen, S. Rysgaard, L.L. Sorensen, P.B. Christensen, and R.N. Glud. 2011. Air-sea flux of $\mathrm{CO}_{2}$ in arctic coastal waters influenced by glacial melt water and sea ice. Tellus Series B-Chemical and Physical Meteorology 63: 815-822. doi:10.1111/j.1600-0889.2011.00540.x.

Sejr, M.K., D. Krause-Jensen, T. Dalsgaard, S. Ruiz-Halpern, C.M. Duarte, M. Middelboe, R.N. Glud, J. Bendtsen, et al. 2014. Seasonal dynamics of autotrophic and heterotrophic plankton metabolism and $\mathrm{pCO}_{2}$ in a subarctic Greenland fjord. Limnology and Oceanography 59: 1764-1778. doi:10.4319/lo.2014.59.5.1764.

Smik, L., P. Cabedo-Sanz, and S.T. Belt. 2016. Semi-quantitative estimates of paleo Arctic sea ice concentration based on sourcespecific highly branched isoprenoid alkenes: A further development of the PIP25 index. Organic Geochemistry 92: 63-69.

Thamdrup, B., R.N. Glud, and J.W. Hansen. 2007. Benthic carbon cycling in Young Sound, Northeast Greenland. Meddelelser om Grønland. Bioscience 58: 138-157.

Wang, L., D. Fan, W. Li, Y. Liao, X. Zhang, M. Liu, and Z. Yang. 2014. Grain-size effect of biogenic silica in the surface sediments of the East China Sea. Continental Shelf Research 81: 29-37.

Wassmann, P., C.M. Duarte, S. Agustí, and M.K. Sejr. 2011. Footprints of climate change in the Arctic marine ecosystem. Global Change Biology 17: 1235-1249. doi:10.1111/j.13652486.2010.02311.x.

Xiao, X., K. Fahl, and R. Stein. 2013. Biomarker distributions in surface sediments from the Kara and Laptev seas (Arctic Ocean): Indicators for organic-carbon sources and sea-ice coverage. Quaternary Science Reviews 79: 40-52. 


\section{AUTHOR BIOGRAPHIES}

Sofia Ribeiro $(\square)$ is a Research Scientist at the Geological Survey of Denmark and Greenland. Her research interests include (palaeo)ecology and evolution of marine primary producers, the reconstruction of past climate and environments using biogenic proxies from marine sediment records, and ocean-climate-human interactions in the Arctic.

Address: Department of Glaciology and Climate, Geological Survey of Denmark and Greenland, Øster Voldgade 10, 1350 Copenhagen K, Denmark.

e-mail: sri@geus.dk

Mikael K. Sejr is a Senior Researcher at the Arctic Research Centre, Aarhus University. His research focuses on function and structure of the Arctic marine ecosystem, with emphasis on the coastal zone around Greenland. He is the Manager of the MarineBasis program in East Greenland.

Address: Arctic Research Centre, Aarhus University, Ny Munkegade bldg. 1540, 8000 Aarhus C, Denmark.

e-mail: mse@bios.au.dk

Audrey Limoges is a Postdoctoral Researcher at the Geological Survey of Denmark and Greenland. Her research activities are motivated by questions regarding the impact of natural environmental and anthropogenic changes on aquatic systems.

Address: Department of Glaciology and Climate, Geological Survey of Denmark and Greenland, Øster Voldgade 10, 1350 Copenhagen K, Denmark.

e-mail: aul@geus.dk

Maija Heikkilä is a Postdoctoral Researcher at the Geological Survey of Denmark and Greenland. Her research is focused on highlatitude environmental and palaeoenvironmental change, in particular on the responses of species and biotic communities to climate change. Address: Environmental Change Research Unit (ECRU), Department of Environmental Sciences, University of Helsinki, P.O. Box 65 (Viikinkaari 1), 00014 Helsinki, Finland.

e-mail: maija.heikkila@helsinki.fi

Thorbjørn Joest Andersen is a Professor at CENPERM, Department of Geosciences and Natural Resource Management, University of Copenhagen. His research is mainly focused on erosion, transport, and deposition of fine-grained material in estuarine and marine environments and climate and environmental reconstruction on the basis of fine-grained deposits.

Address: IGN, Øster Voldgade 10, 1350 Copenhagen K, Denmark. e-mail: tja@ign.ku.dk

Petra Tallberg is a Senior Scientist associated with the University of Helsinki. Her research is focused on the biogeochemical cycling of silicon.

Address: Department of Environmental Sciences, University of Helsinki, P.O. Box 65, 00014 Helsinki, Finland.

e-mail: petra.tallberg@helsinki.fi

Kaarina Weckström is a Research Fellow at the Department of Environmental Sciences, University of Helsinki and an Adjunct Senior Scientist at the Geological Survey of Denmark and Greenland. Her research focuses on the reconstruction of past climate and environments using sediment proxy records.

Address: Environmental Change Research Unit (ECRU), Department of Environmental Sciences, University of Helsinki, P.O. Box 65 (Viikinkaari 1), 00014 Helsinki, Finland.

e-mail: kaarina.weckstrom@helsinki.fi
Katrine Husum is a Senior Researcher at the Norwegian Polar Institute. The overall objective of her research is to reconstruct polar marine environmental and climatic changes in the past using geological proxies. Her work covers different environments from fjords to deep ocean settings in the Arctic.

Address: Fram Centre, Norwegian Polar Institute, P.O. Box 6606, Langnes, 9296 Troms $\varnothing$, Norway.

e-mail: katrine.husum@npolar.no

Matthias Forwick is an Associate Professor at the Department of Geosciences at UiT, The Arctic University of Norway in Troms $\varnothing$. His research focuses on the investigation of sedimentary processes and glacial landforms on glaciated continental margins to reconstruct environmental conditions and the past dynamics of glaciers.

Address: Department of Geosciences, UiT - The Arctic University of Norway in Troms $\varnothing$, Postboks 6050, Langnes, 9037 Troms $\varnothing$, Norway. e-mail: matthias.forwick@uit.no

Tage Dalsgaard is a Senior Researcher at the Arctic Research Centre, Aarhus University. His research interests are the cycling of carbon and nutrients in the marine environment in both water column and sediment.

Address: Arctic Research Centre, Aarhus University, Ny Munkegade bldg. 1540, 8000 Aarhus C, Denmark.

e-mail: tda@bios.au.dk

Guillaume Massé is an Adjoint Professor at the University of Laval in Quebec, and a Senior Researcher at the CNRS, France (TAKUVIK Joint International Laboratory). His research is mainly dedicated to the structural determination and biosynthesis of isoprenoid biomarkers, the development of new biomarkers for palaeoclimatic studies, and understanding the fate of isoprenoid lipids across marine food chains.

Address: Unité Mixte Internationale Takuvik, CNRS \& Université Laval, Pavillon Alexandre-Vachon 1045, Avenue de la Médecine, Québec, QC G1V 0A6, Canada.

e-mail: guillaume.masse@takuvik.ulaval.ca

Marit-Solveig Seidenkrantz is a Professor at the Department of Geoscience, Aarhus University. Her research is focused on understanding the processes controlling climate and ocean variability, using micropalaeontological and multiproxy studies of marine sedimentary archives from the Arctic to the tropics as a primary tool.

Address: Department of Geoscience and Arctic Research Centre, Centre for Past Climate Studies, Aarhus University, Høegh-Guldbergs Gade, 28000 Aarhus C, Denmark.

e-mail: mss@geo.au.dk

Søren Rysgaard is a Professor and holds a Canada Excellence Research Chair at the University of Manitoba, Canada. He is the Founding Director of the Arctic Science Partnership (ASP), the Greenland Climate Research Centre (Greenland), and the Arctic Research Centre (Denmark). His research interests include marine microbiology and biogeochemistry of Arctic sea ice, ocean and sediments; understanding carbon and nutrient cycling in Arctic marine ecosystems; sea ice processes; and glacier-fjord-ocean interactions. Address: Clayton H Riddell Faculty of Environment Earth and Resources, University of Manitoba, Winnipeg, MB R3T 2N2, Canada.

e-mail: rysgaard@umanitoba.ca 